\title{
Guillain-Barré Syndrome in the Placebo and Active Arms of a COVID-19 Vaccine Clinical Trial
}

\section{Temporal Associations Do Not Imply Causality}

Alejandra M. Márquez Loza, MD, Kathryn B. Holroyd, MD, Stephen A. Johnson, MD, David M. Pilgrim, MD, and Anthony A. Amato, MD

Neurology ${ }^{\circledR}$ 2021;96:1052-1054. doi:10.1212/WNL.0000000000011881

There are reports of Guillain-Barré syndrome (GBS) and cranial neuropathies occurring during or shortly after severe acute respiratory syndrome coronavirus 2 (SARS-CoV-2) infection. ${ }^{1,2}$ Some recent infections are known to trigger GBS. A recent epidemiologic cohort study found no evidence for causality between coronavirus disease 2019 (COVID19 ) and GBS. ${ }^{3}$ There is a modest risk of GBS attributed to any vaccination (about 1 to 3 additional cases per million people vaccinated for seasonal influenza), ${ }^{4}$ and this has raised the possibility that the worldwide COVID-19 vaccination campaign may lead to some people developing GBS. ${ }^{5}$ Documents submitted to the Food and Drug Administration for Emergency Use Authorization of the Johnson \& Johnson COVID-19 vaccine, d26.COV2.S, a recombinant, replication-incompetent adenovirus serotype 26 (Ad26) vector encoding a full-length and stabilized SARS-CoV-2 spike protein, however, include reports of 2 patients, 1 in the placebo and 1 in the active arm of the trial, developing GBS within 2 weeks of receiving an injection. ${ }^{6,7}$ Here we report the clinical features of the participant who received the vaccine $\left(5 \times 10^{10}\right.$ viral particles $)$ at the intended dose for clinical practice and discuss why this case cannot be used to establish a causal association between vaccination and the onset of GBS.

\section{Case Report}

A 60-year-old woman with a history of migraines was in her usual state of health when she enrolled in the vaccine trial. Reverse transcriptase polymerase chain reaction (RT-PCR) assay for SARS-CoV-2 and antibody testing were negative at screening prior to vaccination. She received the vaccine on December 10,2020. She remained well without any respiratory or gastrointestinal symptoms until 10 days after vaccination, when she started experiencing pain in her back and legs. She was seen for a study visit 4 days after symptom onset (December 24, 2020) and at that time the PCR assay for SARS-CoV-2 was negative. The next day, she awoke with a headache, nausea, vomiting, and diplopia, and she went to the hospital. The neurologic examination was normal, but she was treated for migraine overnight. The headache and diplopia persisted after discharge and on December 27, 2020, she was readmitted to the hospital, this time in the neurology service. Examination that day showed left eye esotropia on midline gaze and bilateral ocular abduction deficits but the strength, sensation, and reflexes in her limbs were normal. By the next day, her symptoms had progressed to bilateral facial weakness as well as numbness, areflexia, and $2 / 5$ weakness of both legs. MRI of the lumbar spine demonstrated enhancement of the cauda equina (figure). Brain MRI was normal. Lumbar puncture revealed an increased opening pressure $\left(29 \mathrm{~cm} \mathrm{H}_{2} \mathrm{O}\right)$ and the CSF had elevated protein $(140 \mathrm{mg} / \mathrm{dL}), 9$ nucleated cells, and normal

\section{Correspondence}

Dr. Amato

aamato@bwh.harvard.edu

RELATED ARTICLE

\section{Editorial}

Quelling Public Fears

About Guillain-Barré

Syndrome and COVID-19

Vaccination

Page 1021 


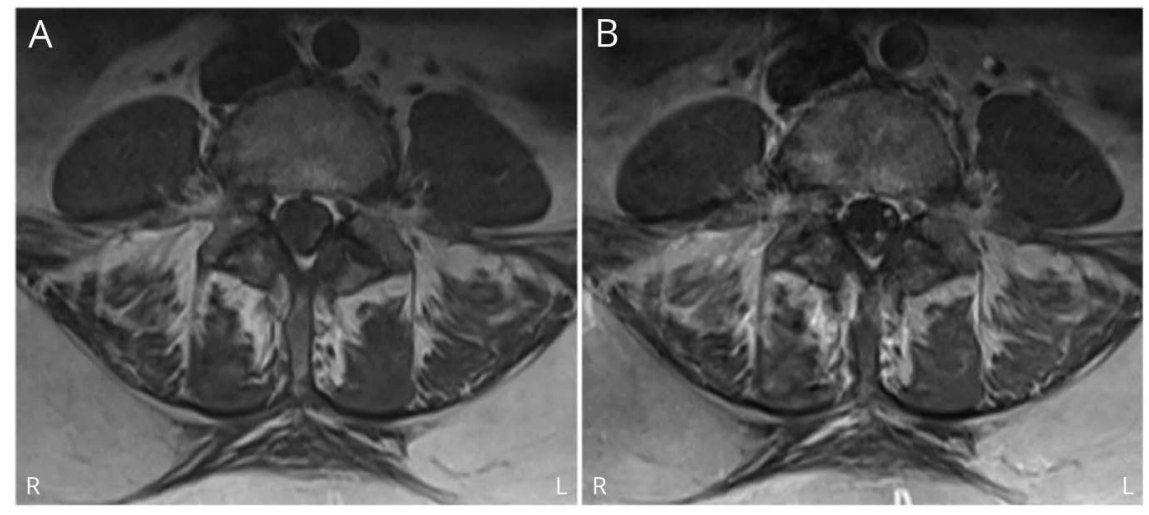

Axial cuts T1 precontrast (A) and postcontrast (B) show cauda equina enhancement.

glucose $(63 \mathrm{mg} / \mathrm{dL})$. Electrophysiologic studies done 2 days after admission showed normal compound muscle and sensory nerve action potentials and absent late responses (peroneal and posterior tibialis F-waves and $\mathrm{H}$-reflexes) in the legs. Needle EMG showed neurogenic recruitment (fast firing units) in leg muscles. These findings are the earliest electrophysiologic abnormalities seen in GBS. Antiganglioside antibodies were negative. RT-PCR for SARS$\mathrm{CoV}-2$ was repeated twice during admission and resulted negative. She was treated with IV immunoglobulin $2 \mathrm{~g} / \mathrm{kg}$ over 2 days starting on December 29, 2020. Her strength slowly improved and she was discharged to rehabilitation 10 days after admission.

\section{Discussion}

Two patients in the Johnson \& Johnson COVID-19 vaccine trial developed GBS 10 days after injection: 1 was in the placebo arm and 1 was in the active vaccine arm. The incidence of GBS was identical in both arms of the trial. Our patient in the vaccine arm did not have any clinical features differentiating her from patients with typical GBS. From the available evidence, it is not possible to draw causal inferences about the association of COVID-19 vaccination and the development of GBS. To avoid misattributing adverse events to the COVID-19 vaccine, and to clarify whether the risk of GBS is equal to or higher than the baseline rate in the population, or to the attributable risk reported for other vaccines such as the seasonal influenza A vaccine, large-scale epidemiologic studies and meta-analyses of data from several adverse event monitoring systems are needed, as was the case with prior pandemics and large-scale vaccination studies (e.g., for H1N1). ${ }^{4}$ In the setting of global vaccination efforts, it is impossible to conclude that any particular case is related to the vaccine. A large meta-analysis revealed the annual crude incidence of GBS among adults is about 8-19 per million $^{8}$; we expect that among 1 billion people, around 8,000-19,000 will develop GBS each year. This means that as we advance toward the goal of vaccinating 1 billion people against COVID-19 (and hopefully the number will be much higher), many people will develop GBS by coincidence within a few weeks of vaccination. ${ }^{9}$ By chance alone, we would expect to see 900-2,200 people develop GBS within 6 weeks of receiving a 1-dose vaccine (e.g., Johnson \& Johnson) or 1,500-3,700 within a 10-week period from a 2-dose vaccination approach (e.g., Pfizer and Moderna). We must be careful to avoid misattributing adverse events to the vaccination program. ${ }^{9}$ Temporal associations do not imply causality. The fact that 1 other participant in the Johnson \& Johnson vaccine trial also developed GBS 10 days after being injected with placebo supports the argument for a coincidental rather than a causal association. Neurologists must educate and reassure their patients, the public, and policy makers regarding the safety and rationale of COVID19 vaccinations as more reports of GBS and other autoimmune diseases will likely emerge. Based on experience with other vaccination initiatives and the data in the adverse monitoring systems of the COVID-19 vaccines gathered so far, the benefits of vaccination outweigh the risks of COVID19 infection and associated morbidity and mortality. We advise our patients with prior GBS that there is no contraindication to receiving any COVID-19 vaccination and that they should get vaccinated as soon as they can.

\section{Study Funding}

The authors report no targeted funding.

\section{Disclosure}

Dr. Márquez Loza, Dr. Holroyd, Dr. Johnson, and Dr. Pilgrim report no disclosures. Dr. Amato has served on medical advisory boards for Johnson \& Johnson, Alexion, Sarepta, CSL Behring, and Strongbridge Pharma. Go to Neurology.org/N for full disclosures.

\section{Publication History}

Received by Neurology January 21, 2021. Accepted in final form March 11, 2021. 


\section{Appendix Authors}

\begin{tabular}{|c|c|c|}
\hline Name & Location & Contribution \\
\hline $\begin{array}{l}\text { Alejandra } \\
\text { M. Márquez } \\
\text { Loza, MD }\end{array}$ & $\begin{array}{l}\text { Department of Neurology, } \\
\text { Brigham and Women's } \\
\text { Hospital, Boston, MA }\end{array}$ & $\begin{array}{l}\text { Drafting/revision of the } \\
\text { manuscript for content, } \\
\text { including medical writing } \\
\text { for content; major role in } \\
\text { the acquisition of data; } \\
\text { analysis or interpretation of } \\
\text { data }\end{array}$ \\
\hline $\begin{array}{l}\text { Kathryn B. } \\
\text { Holroyd, } \\
\text { MD }\end{array}$ & $\begin{array}{l}\text { Department of Neurology, } \\
\text { Brigham and Women's } \\
\text { Hospital, Boston, MA }\end{array}$ & $\begin{array}{l}\text { Major role in the acquisition } \\
\text { of data; study concept or } \\
\text { design; analysis or } \\
\text { interpretation of data }\end{array}$ \\
\hline $\begin{array}{l}\text { Stephen A. } \\
\text { Johnson, } \\
\text { MD }\end{array}$ & $\begin{array}{l}\text { Department of Neurology, } \\
\text { Brigham and Women's } \\
\text { Hospital, Boston, MA }\end{array}$ & $\begin{array}{l}\text { Drafting/revision of the } \\
\text { manuscript for content, } \\
\text { including medical writing } \\
\text { for content; major role in } \\
\text { the acquisition of data; } \\
\text { analysis or interpretation of } \\
\text { data }\end{array}$ \\
\hline $\begin{array}{l}\text { David M. } \\
\text { Pilgrim, MD }\end{array}$ & $\begin{array}{l}\text { Department of Neurology, } \\
\text { Brigham and Women's } \\
\text { Hospital, Boston, MA }\end{array}$ & $\begin{array}{l}\text { Drafting/revision of the } \\
\text { manuscript for content, } \\
\text { including medical writing } \\
\text { for content; analysis or } \\
\text { interpretation of data }\end{array}$ \\
\hline $\begin{array}{l}\text { Anthony A. } \\
\text { Amato, MD }\end{array}$ & $\begin{array}{l}\text { Department of Neurology, } \\
\text { Brigham and Women's } \\
\text { Hospital, Boston, MA }\end{array}$ & $\begin{array}{l}\text { Drafting/revision of the } \\
\text { manuscript for content, } \\
\text { including medical writing } \\
\text { for content; major role in } \\
\text { the acquisition of data; } \\
\text { study concept or design; } \\
\text { analysis or interpretation of } \\
\text { data }\end{array}$ \\
\hline
\end{tabular}

\section{References}

1. Gutiérrez-Ortiz C, Méndez-Guerrero A, Rodrigo-Rey S, et al. Miller Fisher syndrome and polyneuritis cranialis in COVID-19. Neurology. 2020;95:601-605.

2. Toscano G, Palmerini F, Ravaglia S, et al. Guillain-Barré syndrome associated with SARS-CoV-2. N Engl J Med. 2020;382:2574-2576.

3. Keddie S, Pakpoor J, Mousele C, et al. Epidemiological and cohort study finds no association between COVID-19 and Guillain-Barré syndrome. Brain. 2021;144: 682-693.

4. Salmon DA, Proschan M, Forshee R, et al. Association between Guillain-Barre syndrome and influenza A (H1N1) 2009 monovalent in-activated vaccines in the USA: a meta-analysis. Lancet. 2013;381:1461-1468.

5. Guidon AC, Amato AA. COVID-19 and neuromuscular disorders. Neurology. 2020; 94:959-969.

6. FDA Briefing Document. Janssen Ad26.COV2.S vaccine for the prevention of COVID-19: vaccines and related biological products advisory committee meeting. 2020. Accessed March 22, 2021. fda.gov/media/146217/download.

7. Sadoff J, Le Gars M, Shukarev G, et al. Interim results of a phase 1-2a trial of Ad26.COV2.S covid-19 vaccine. N Engl J Med. Epub 2021 Jan 13.

8. Sejvar JJ, Baughman AL, Wise M, Morgan OW. Population incidence of Guillain Barre syndrome: a systematic review and meta-analysis. Neuroepidemiology. 2011;36: 123-133.

9. Lunn MP, Cornblath DR, Jacobs BC, et al. COVID-19 vaccine and Guillain-Barré syndrome: let's not leap to associations. Brain. 2021;144:357-360.

\section{Sign Up for the AAN's Axon Registry}

The AAN encourages its US members to show their interest in participating in the Axon Registry by signing up today.

Use the Axon Registry to:

- Simplify reporting requirements under MACRA's Quality Payment Program and avoid penalties while reducing your administrative burden

- Meet your MOC Part IV requirements and waive up to eight credits of Part II Self-Assessment

- Choose from 22 AAN neurology-specific quality measures that fit your practice

- Use data to understand your practice and identify where improvements can be made to patient care

- Manage your patients at a population level; look at a specific group of patients based on conditions, risk factors, demographics or outcome

- Demonstrate your value to payers when negotiating reimbursement

- Enjoy multi-year, fee-free access when you sign the agreements and integrate your EHR with the registry

Learn more at AAN.com/view/Axon and send your questions to registry@aan.com. 


\section{Neurology}

\section{Guillain-Barré Syndrome in the Placebo and Active Arms of a COVID-19 Vaccine Clinical Trial: Temporal Associations Do Not Imply Causality}

Alejandra M. Márquez Loza, Kathryn B. Holroyd, Stephen A. Johnson, et al. Neurology 2021;96;1052-1054 Published Online before print April 6, 2021

DOI 10.1212/WNL.0000000000011881

\section{This information is current as of April 6, 2021}

\section{Updated Information \& Services}

References

Citations

Subspecialty Collections

Permissions \& Licensing

Reprints including high resolution figures, can be found at: http://n.neurology.org/content/96/22/1052.full

This article cites 7 articles, 2 of which you can access for free at: http://n.neurology.org/content/96/22/1052.full\#ref-list-1

This article has been cited by 4 HighWire-hosted articles: http://n.neurology.org/content/96/22/1052.full\#\#otherarticles

This article, along with others on similar topics, appears in the following collection(s):

COVID-19

http://n.neurology.org/cgi/collection/covid_19

EMG

http://n.neurology.org/cgi/collection/emg

Guillain-Barre syndrome

http://n.neurology.org/cgi/collection/guillainbarre_syndrome

Information about reproducing this article in parts (figures,tables) or in its entirety can be found online at:

http://www.neurology.org/about/about_the_journal\#permissions

Information about ordering reprints can be found online:

http://n.neurology.org/subscribers/advertise

Neurology ${ }^{\circledR}$ is the official journal of the American Academy of Neurology. Published continuously since 1951, it is now a weekly with 48 issues per year. Copyright () 2021 American Academy of Neurology. All rights reserved. Print ISSN: 0028-3878. Online ISSN: 1526-632X.

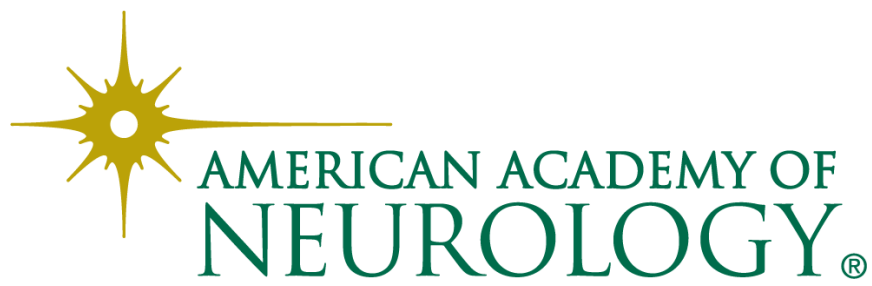

